Iraqi Journal of Industrial Research (IJOIR)

\title{
Improving the Performance of Solar Heat Collector Using Molten Salts
}

\author{
Alaa H. Salloom*, Ban H. Ismail, Saad M. Awaad, Ammar H. Khalaf \\ Renewable Energy and Environment Research Center/Corporation of Research and Industrial Development - Iraq
}

\section{Article information}

Article history:

Received: April, 19, 2021

Accepted: September, 20, 2021

Available online: December, 14, 2021

Keywords:

Phase change materials,

Thermal energy storage,

Low molten salt

*Corresponding Author:

Alaa H. Salloom

alaa.salum@gmail.com

DOI:

https://doi.org/10.53523/ijoirVol8I3ID40

\begin{abstract}
An individual solar collector and two partly freight cylinders filled with molten salts embedded storage tank were connected to each other and forced circulated water by electric pump to improve the thermal performance of residential solar hot water tank. Multi flow rates of 25, 50 and $70 \mathrm{l} / \mathrm{h}$. used to achieve an appropriate flow rate of circulating water. The calcium nitrate tetra hydrate $\mathrm{Ca}\left(\mathrm{NO}_{3}\right)_{2}-4 \mathrm{H}_{2} \mathrm{O}$ and magnesium nitrate hex hydrate $\mathrm{Mg}\left(\mathrm{NO}_{3}\right)_{2}-6 \mathrm{H}_{2} \mathrm{O}$ were mixed to form cheap binary molten salts base on different weight ratios. These molten salts combined could be used as both sensible heat materials and latent heat storage materials, besides they can directly use as heat transfer fluid due to freezing temperature. Six samples of different mixing ratio of molten salts had tested to assess the thermal analysis of each sample. The result indicated that the mixture $60 \% \mathrm{Ca}\left(\mathrm{NO}_{3}\right)_{2}+40 \% \mathrm{Mg}\left(\mathrm{NO}_{3}\right)_{2}$ had the best performance for thermal storage tank with melting point of $38^{\circ} \mathrm{C}$ and the thermal value is $8.7 \mathrm{~mW}$, and thermal stability of molten salts were noticed by DSC 60 SHIMADZSU devise.
\end{abstract}

\section{Introduction}

Because of the limitation of fossil fuel resources and environmental pollutions which created by this type of fuel it was necessary to find a useful tool to storage energy and increasing energy efficiency. By the energy storage in various type like chemical, thermal and mechanical during the day can overcome the main problem in using solar energy such as the various of the sunlight during the day and the absence of the sunlight at night [1].

The solar thermal research centres worked on developing and improving storage systems, as they worked to increase efficiency through the use of storage fluids with a low melting point and higher thermal stability through the use of molten salts. Experiments were conducted to measure the effects of the molten salts receiver freeze up and recovery event and method to the receiver [2].

In last decade's reservation have been worked at Renewable energy to find an optimum solution for global warming and climate changes to reduce $\mathrm{CO}_{2}$ emission by finding an alternative energy of fossil oil like a solar thermal energy for residual heating and cooling. The first use of molten salts dates back to 1950, which is when Oak Ridge National Laboratory (ORNL) started to develop and test a nuclear powered aircraft engine using molten salts. In 1954, ORNL shifted their molten salt focus to nuclear reactors. The thermal stability of molten salts was of great interest in the development of these nuclear reactors since they would not decompose when exposed to 
the high temperatures associated with nuclear reactors. The U.S. Atomic Energy Commission (AEC) was interested in studying various breeding reactor concepts. A relatively successful molten salt test breeding reactor was developed in the 1960s at ORNL [3].

Yang and Garimella extended modeling work to include density change of the phase change materials (PCM) during phase change. The effect of including volume shrinkage in the PCM into the simulation was increase the melting rate [4]. Laing et al studied the use of latent heat within a three component storage system for the generation in the power block during short periods of low solar irradiance [5]. Voral et al experimentally investigated the use of sodium carbonate de carbohydrate $\left(\mathrm{Na}_{2} \mathrm{Co}_{3}-10 \mathrm{H}_{2} \mathrm{O}\right)$ as PCM in solar collector the efficiency of this collector was compared with that of the conventional system without PCM to predict collector Performance [6]. Haillot et al evaluated the performance of domestic hot water (DHW) System with PCM. In this system PCM was inserted into flat plate solar collector to replace the collector absorber. The researchers applied four types of PCMs (Sodium -actate trihydrate, RT 5 Paraffin, stearic acid, and pentaglycerin) to optimize PCM and synthesized the different physical properties of the PCM, including thermal conductivities, absorptive, Storage capacity and PCM life time, the result suggested that the characteristics of the three of four composites were suitable for integration into solar collector [7]. Mehrdad et al found that the stratification of the storage tank ill increases the annual solar fraction up to about $4.6 \%$. Additionally, it is found that the optimum amount for the PCM and its melting temperature is changed as the tank stratification goes from the fully mixed to the fully stratified state [8]. Tayeb et al developed a system for domestic hot water using $\mathrm{Na}_{2} \mathrm{SO} 4.10 \mathrm{H}_{2} \mathrm{O}$ as a PCM and compared with the simulation model which gives the optimum flow rate of the inlet water supply required to maintain the constant Temperature [9].

In this work binary molten salts Calcium nitrate tetra hydrate $\mathrm{Ca}\left(\mathrm{NO}_{3}\right)_{2}-4 \mathrm{H}_{2} \mathrm{O}$ and magnesium nitrate hex hydrate $\mathrm{Mg}\left(\mathrm{NO}_{3}\right)_{2}-6 \mathrm{H}_{2} \mathrm{O}$ with low melting point were used in six different ratio mixtures by weight, the samples were prepared and analyzed. Appropriate samples were selected for the binary mixture of salts with weight ratios $(60 \%)$ and $(40 \%)$ of calcium nitrate and magnesium nitrate respectively for experiments on their use in thermal storage. Two cylindrical metals Cans were used. The weight of the salt mixture inside each Refill was (0.430) $\mathrm{kg}$, they were placed inside the heat storage tank which contains two coils (collector heating coil) and (domestic heating water coil). For the purpose of identification, the thermal storage applicability of the samples used a comparison was prepared for this study using the water in the capsule as a thermal storage. It was found that the period of processing hot water when using a salt capsule was longer than of water used in the same Refill. The binary mixtures were used showed good physicochemical properties; the low melting point can improve the work temperature range in commercial solar plants. By using differential scanning calorimeter (DSC) various properties can be analyzed such as. melting point, heat capacity and thermal stability. Melting point and heat capacity and thermal stability are the most important characteristics to be taken into consideration when designing any salt storage system [10,11]. Thermal properties for PCM materials include (Suitable phase-transition temperature, good heat transfer and high latent heat of transition), and physical properties include (high density, small volume change and low vapor pressure) and the chemical properties (no toxicity, long term chemical stability, and nonexplosive) [12]. One of disadvantages of molten salts is the low thermal conductivity, that cause slow chargedischarge rates, to overcome this problem is to mix molten salts with graphite for example, can promote thermal conductivity and boost faster energy storage and releasing. Every storage method mentioned can play an important role in several energy storage system designs [13].

\section{Experimental Procedure}

A minuscule model of a solar heating system consists of a flat plate solar collector with dimensions of $25 \times 25$ $\mathrm{cm}^{2}$ covered by a double glass thickness $(4 \mathrm{~mm})$ was used with a stainless steel storage tank thermally insulated with glass wool. Thermal energy storage tank (TES) consist of two coils filled with water and immerse in a two metal Refills contain a binary molten salts with weight ratio [60\% $\mathrm{Ca}\left(\mathrm{NO}_{3}\right)_{2}$ and $40 \% \mathrm{Mg}\left(\mathrm{NO}_{3}\right)_{2}$ ] respectively were choose according to high thermal objectivity of salt mixture, and the weight of the molten salt for each capsule was $430 \mathrm{~g}$. The two coils of the storage tank separated from each other to insure none mixing of solar heating cycling water with thermal storage tank and the other coil used to supply hot water for domestic using. Water pump used to circulate the water from collector to TES throw flow meter with a globe valve to control the flow of heating water. The solar collector is installed at an angle of $45^{\circ}$ to the horizontal and an azimuth angle $22^{\circ}$ towards the southeast. The K type thermocouples were used and fixed in each of molten salts Refill $\mathrm{T}_{1}$ for the 
upper Refill and $\mathrm{T}_{2}$ for the lower Refill, $\mathrm{T}$ storage for the thermal storage tank and $\mathrm{T}_{5}$ for collector outlet and solar irradiance radiation was measured for each recording data. Figure (1) shows the components of the thermal system used.

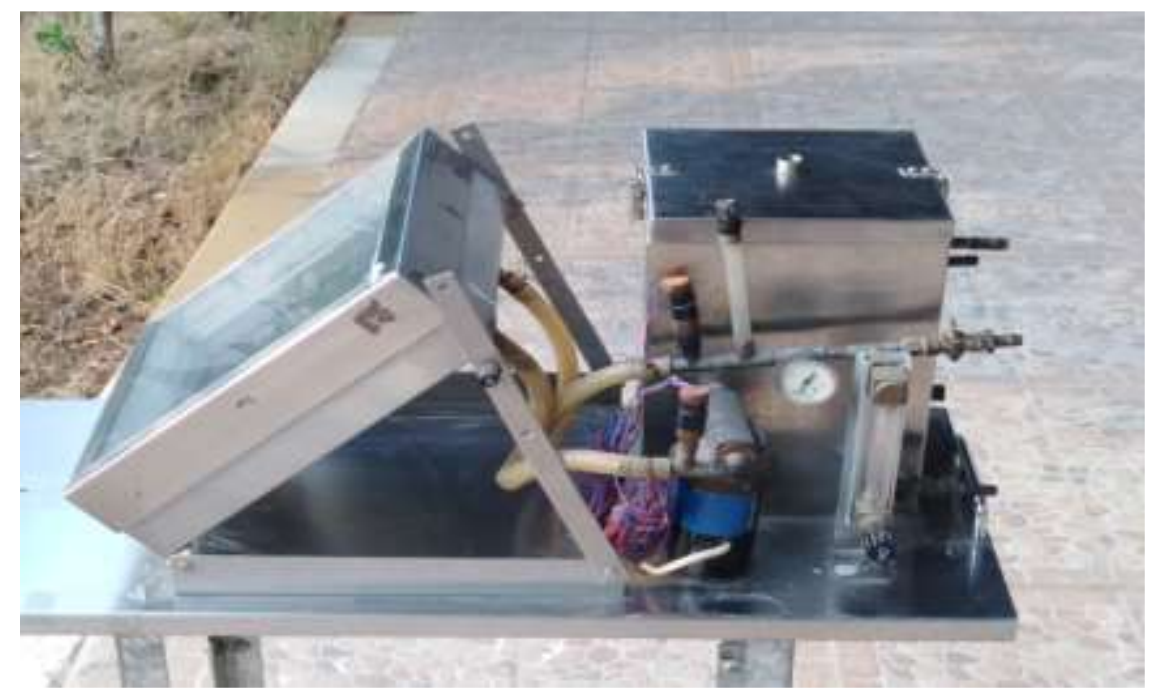

Figure (1). The components of solar collector system.

\section{The equipment used:}

1. Solar power meter (SPM -1116SD), Spectral response - (400 to 1100) nm.

2. 12 channels Temperature Recorder, Type $\mathrm{K}$ thermocouple.

3. DSC-60 Differential scanning calorimeter. Figure (2) shows the used equipment. Temperature range : -140 to $600^{\circ} \mathrm{C}$, Measurement range : $\pm 150 \mathrm{~mW}$

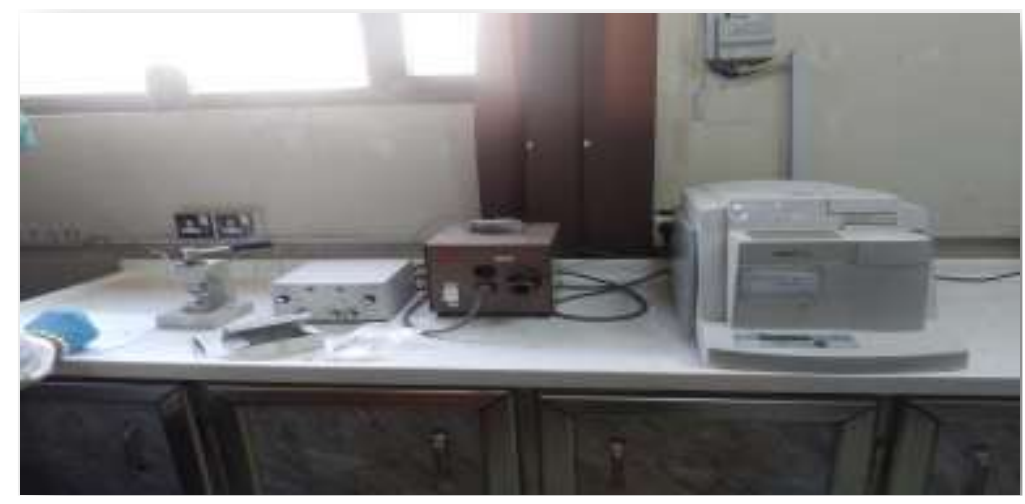

Figure (2). Differential scanning calorimeter equipment (DSC-60).

\section{Results and Discussion}

The DSC analysis for the selected samples is shown in Table (1). The results shown that the melting point of each mixture is nearly to the barriers of this work $30-70^{\circ} \mathrm{C}$. The thermal analysis experiment for sample (3) give good sign for using this binary ratio as a thermal energy storage for domestic solar water heat because the perfusion occurs at melting point $38^{\circ} \mathrm{C}$.

In Figure (3) sample 1, the mixture salt ratio used $\left(85 \% \mathrm{Ca}\left(\mathrm{No}_{3}\right)_{2}+15 \% \mathrm{Mg}\left(\mathrm{No}_{3}\right)_{2}\right)$ shows thermal properties and melting point approximately the same as of pure $\mathrm{Ca}\left(\mathrm{NO}_{3}\right)_{2}$ so it be neglected for this work.

In Figure (4) sample 2, the ratio of the salt $\mathrm{Ca}\left(\mathrm{NO}_{3}\right)_{2}$ was reduced to $70 \%$ and the salt ratio of $\mathrm{Mg}\left(\mathrm{No}_{3}\right)_{2}$ raised to $30 \%$ the melting point increased with the increasing of the thermal value. The melting point was nearly to $52^{\circ} \mathrm{C}$ the heat capacity reach $10.5 \mathrm{~mW}$. 
Table (1). The melting point and heat flow for different mixture salts ratio.

\begin{tabular}{|c|c|c|c|}
\hline Samples & Composition $\mathbf{W t \%}$ & $\begin{array}{c}\text { Melting } \\
\text { point } \\
\left({ }^{\circ} \mathbf{C}\right)\end{array}$ & $\begin{array}{c}\text { Thermal value at } \\
\text { melting point } \\
(\mathbf{m W})\end{array}$ \\
\hline Sample 1 & $85 \% \mathrm{Ca}\left(\mathrm{No}_{3}\right)_{2}+15 \% \mathrm{Mg}\left(\mathrm{No}_{3}\right)_{2}$ & 50 & 3.8 \\
\hline Sample 2 & $70 \% \mathrm{Ca}\left(\mathrm{NO}_{3}\right)_{2}+30 \% \mathrm{Mg}\left(\mathrm{No}_{3}\right)_{2}$ & 52 & 10.5 \\
\hline Sample 3 & $60 \% \mathrm{Ca}\left(\mathrm{NO}_{3}\right)_{2}+40 \% \mathrm{Mg}\left(\mathrm{NO}_{3}\right)_{2}$ & 38 & 8.7 \\
\hline Sample 4 & $45 \% \mathrm{Ca}\left(\mathrm{No}_{3}\right)_{2}+55 \% \mathrm{Mg}\left(\mathrm{NO}_{3}\right)_{2}$ & 50 & 10 \\
\hline Sample 5 & $30 \% \mathrm{Ca}\left(\mathrm{NO}_{3}\right)_{2}+70 \% \mathrm{Mg}\left(\mathrm{No}_{3}\right)_{2}$ & 43 & 11 \\
\hline Sample 6 & $15 \% \mathrm{Ca}\left(\mathrm{No}_{3}\right)_{2}+85 \% \mathrm{Mg}\left(\mathrm{No}_{3}\right)_{2}$ & 47 & 10.5 \\
\hline
\end{tabular}

In Figure (5) sample 3, the ratio of the salt $\mathrm{Ca}\left(\mathrm{NO}_{3}\right)_{2}$ was reduced to $60 \%$ and the salt ratio of $\mathrm{Mg}\left(\mathrm{No}_{3}\right)_{2}$ raised to $40 \%$ the melting point also reduced to $38^{\circ} \mathrm{C}$ and the heat value at this point is $8.7 \mathrm{~mW}$. It shown that this ratio has the low melting point. The thermal properties of this mixture $\left[60 \% \mathrm{Ca}\left(\mathrm{No}_{3}\right)_{2}\right.$ and $\left.40 \% \mathrm{Mg}\left(\mathrm{No}_{3}\right)_{2}\right]$ as shown can be used as a thermal storage media because it has stabile conduct for using in low temperature storage.

In Figure (6) sample 4, the mixture salt ratio was $45 \%$ of $\mathrm{Ca}\left(\mathrm{NO}_{3}\right)_{2}$ and $55 \%$ of $\mathrm{Mg}\left(\mathrm{No}_{3}\right)_{2}$ we obtained melting point reached $50^{\circ} \mathrm{C}$ and thermal value $10 \mathrm{~mW}$. This value would be suitable for using in the range higher from that using in this study.

In Figure (7) sample 5, the mixture salt ratio was $30 \%$ of $\mathrm{Ca}\left(\mathrm{NO}_{3}\right)_{2}$ and $70 \%$ of $\mathrm{Mg}\left(\mathrm{No}_{3}\right)_{2}$ the melting point for this sample decreased to $43^{\circ} \mathrm{C}$ and thermal value increased to $11 \mathrm{~mW}$, it also can be used in low thermal storage application.

In Figure (8) sample 6, the binary salts mixture ratio $15 \%$ of $\mathrm{Ca}\left(\mathrm{NO}_{3}\right)_{2}$ and $85 \%$ of $\mathrm{Mg}\left(\mathrm{No}_{3}\right)_{2}$ the behavior of this mixture is same as the behavior of pure $\mathrm{Mg}\left(\mathrm{NO}_{3}\right)_{2}$.

The thermal cycle of the binary mixture salts would be a good sign for the mixture salts long life. In Figure (9), the flow rate was $25 \mathrm{l} / \mathrm{h}$. the thermal storage temperature reached $58^{\circ} \mathrm{C}$ and the figure shows gradually increase in the temperature of $T_{1}$ for the upper Refill and $T_{2}$ for the lower Refill and $T$ storage for the thermal storage tank. The temperature convergence at mid-day its indication of good heat transference from the storage tank to the refills.

Figure (10) shows that at flow rate $50 \mathrm{l} / \mathrm{h}$. the refills temperature near to $60^{\circ} \mathrm{C}$ while the storage tank temperature was $58^{\circ} \mathrm{C}$ which mean increasing refills temperature with increasing of the flow rate.

In Figure (11), the behavior of the temperatures of $\mathrm{T}_{1}$ for the upper Refill and $\mathrm{T}_{2}$ for the lower Refill and $\mathrm{T}_{5}$ for collector outlet after mid-day are equal and reached $60^{\circ} \mathrm{C}$, that's mean that at increasing flow rate we obtain a stable temperature.

Figure (12) shows a temperature comparison between the binary mixture salts and water was used. The curve indicates that the thermal conductivity of the mixture salts is less than of water.

The optimum flow rate of solar collector water is $50 \mathrm{l} / \mathrm{h}$. As shown in Figure (13) as the molten salts used as storage media. In Figures (14\& 15), the effect of the mass withdrawal for water and salts mixture as a storage media, that show the temperature of the salt mixture storage is higher than water was used. 


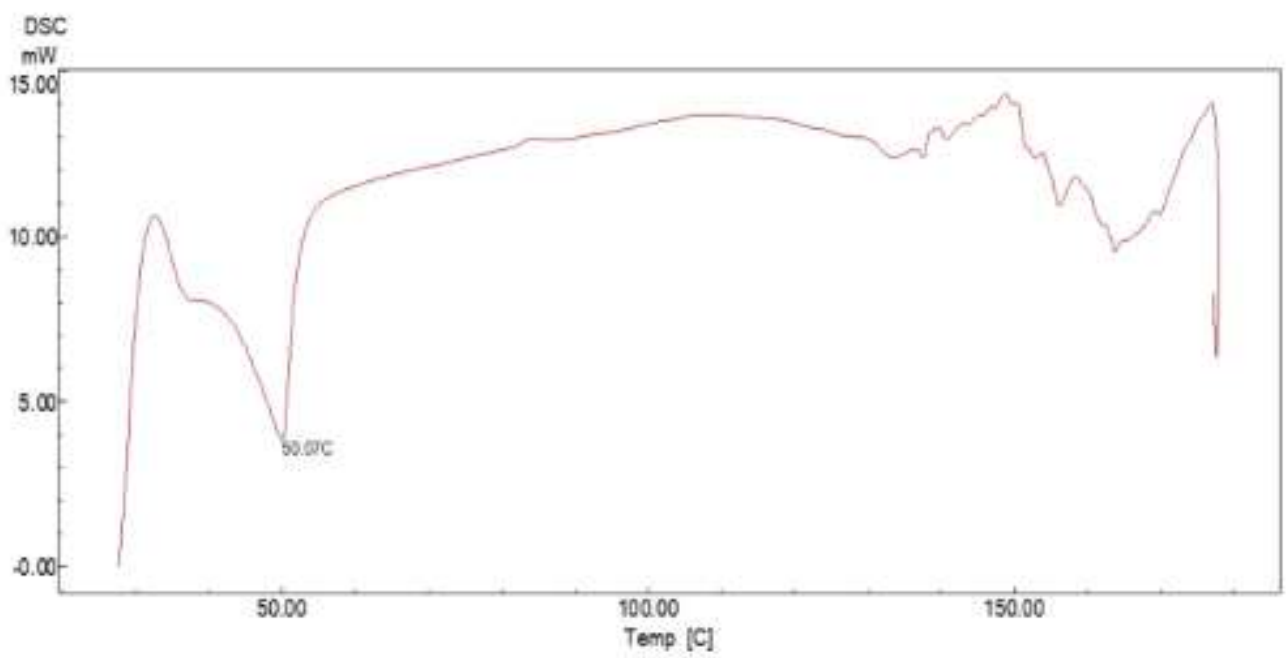

Figure (3). Thermal analysis of Sample 1.

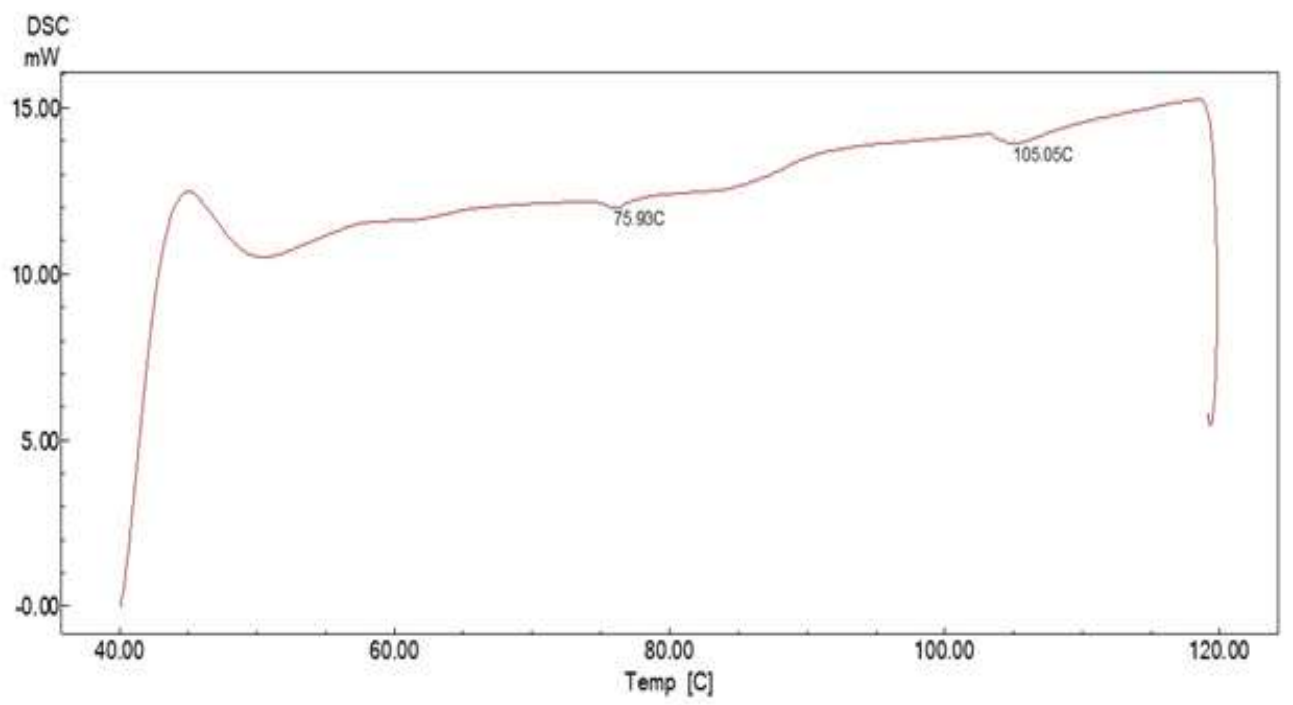

Figure (4). Thermal analysis of Sample 2.

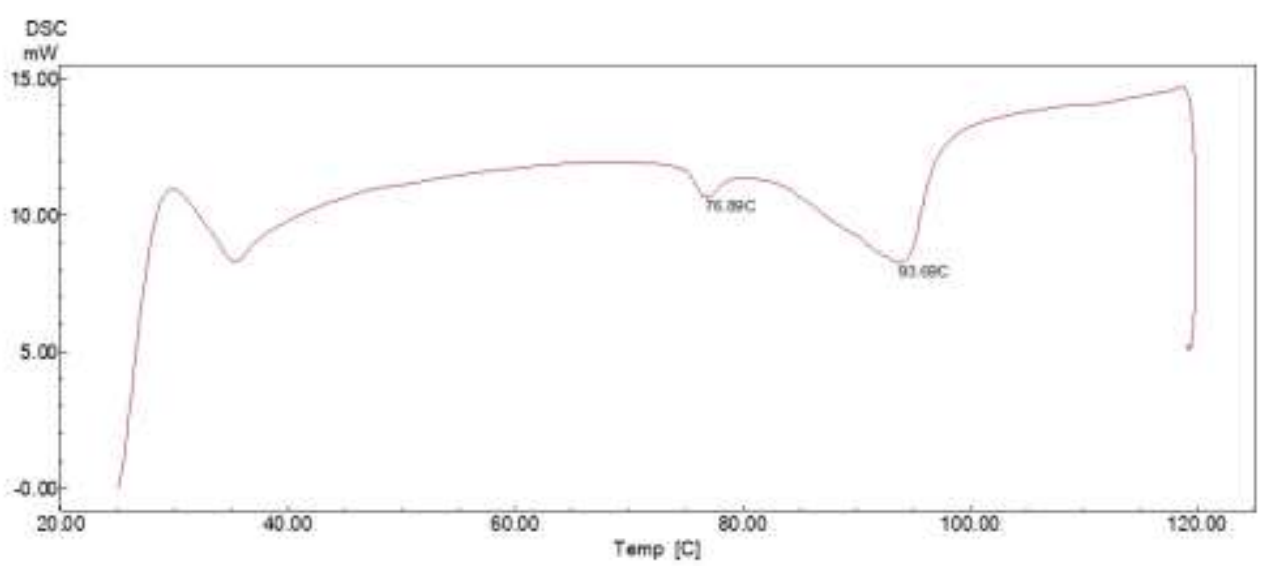

Figure (5). Thermal analysis of Sample 3. 


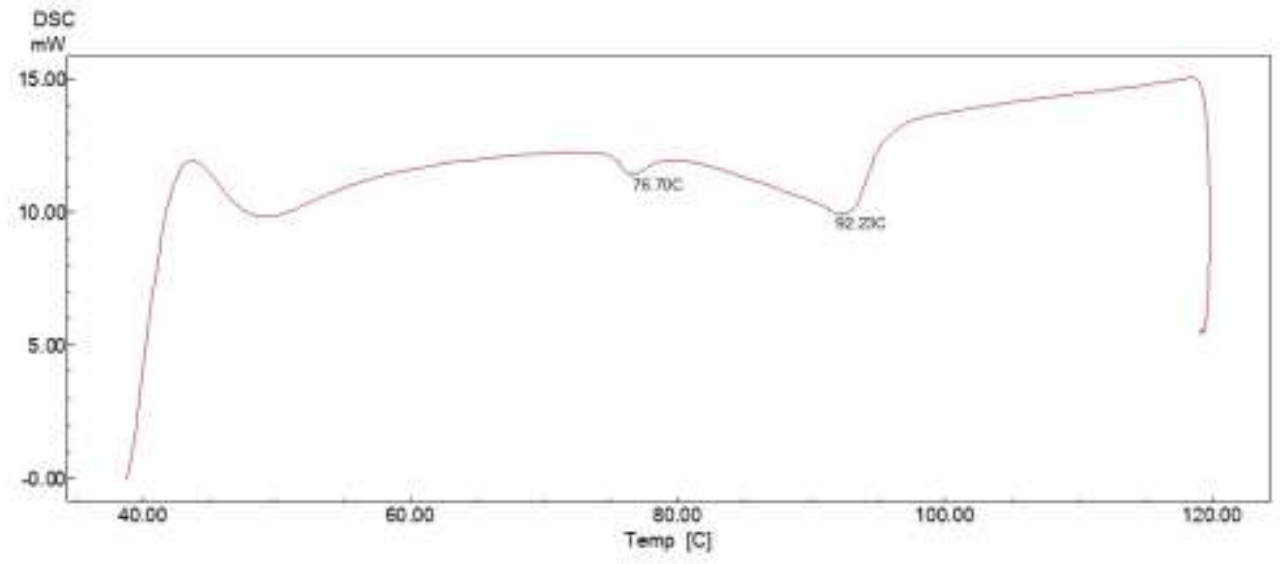

Figure (6). Thermal analysis of Sample 4.

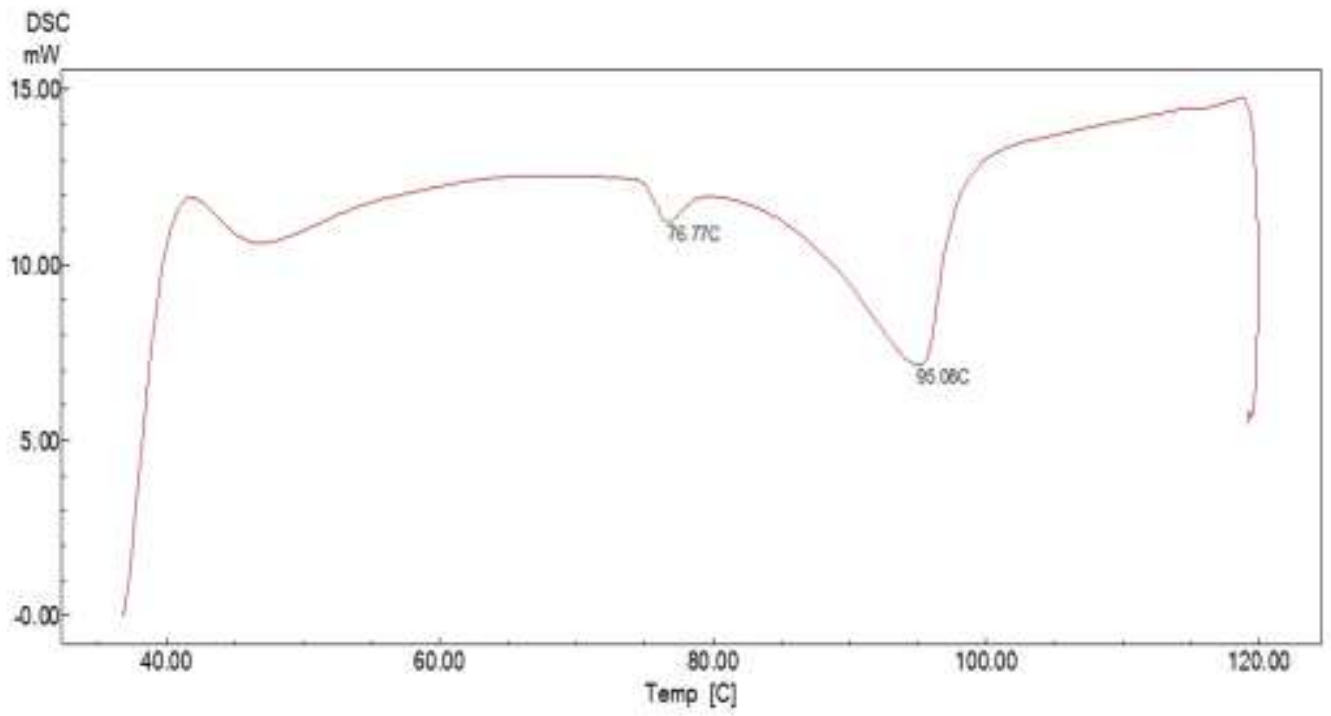

Figure (7). Thermal analysis of Sample 5.

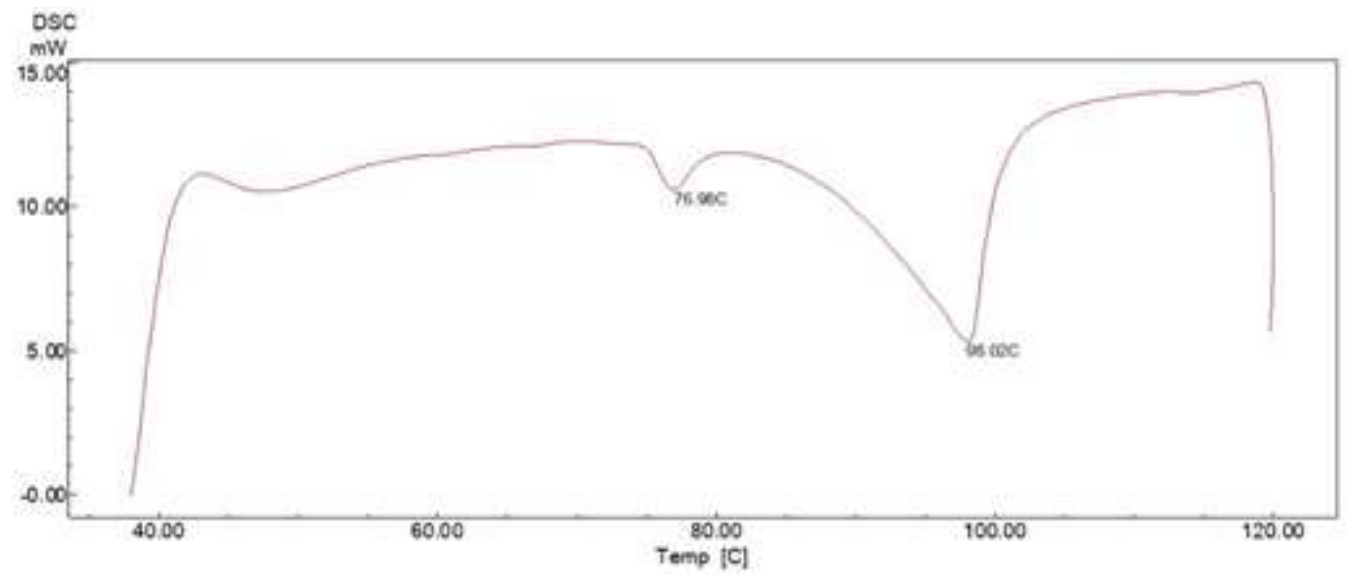

Figure (8). Thermal analysis of sample 6 . 


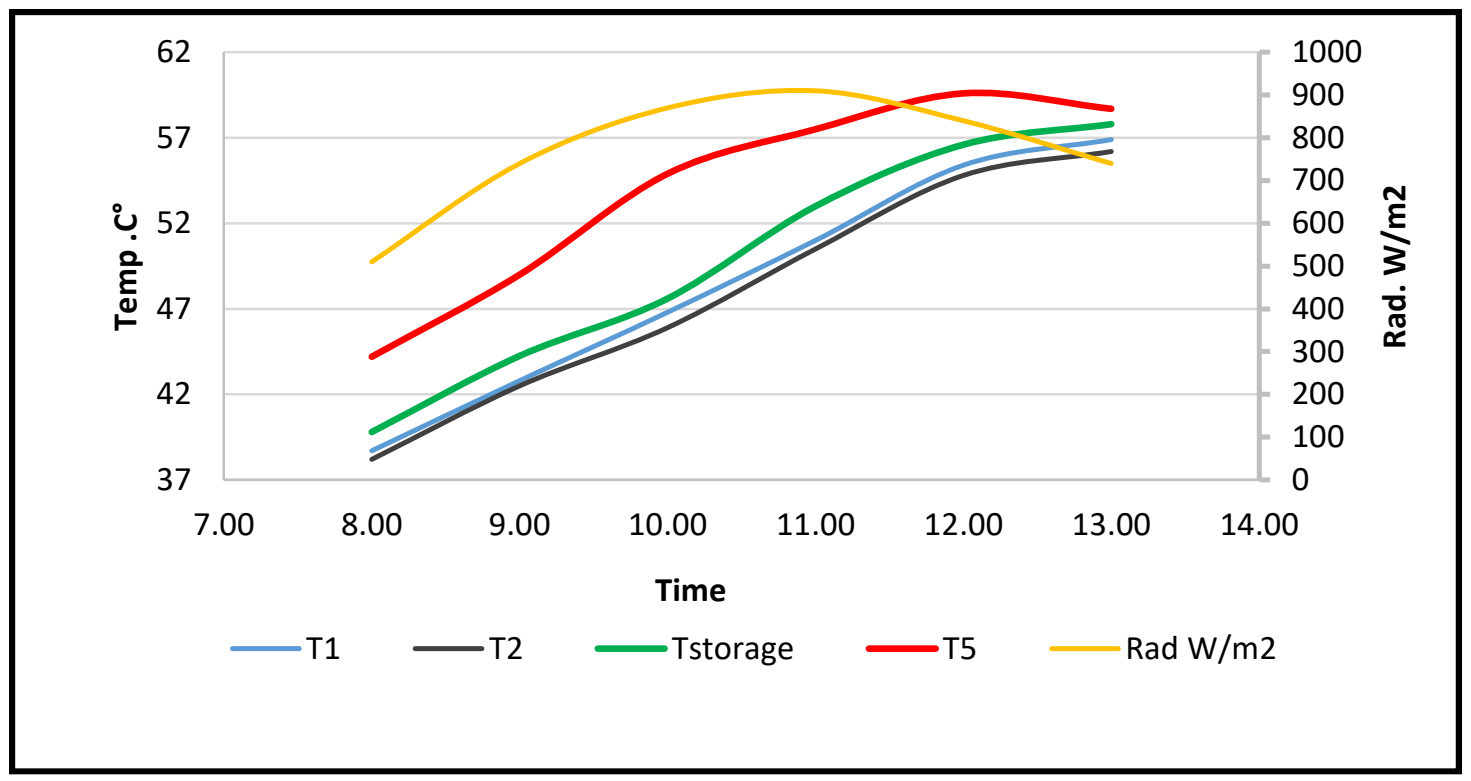

Figure (9). Relation between the temperature of system parameters, solar radiation with time at flow rate 251/h.

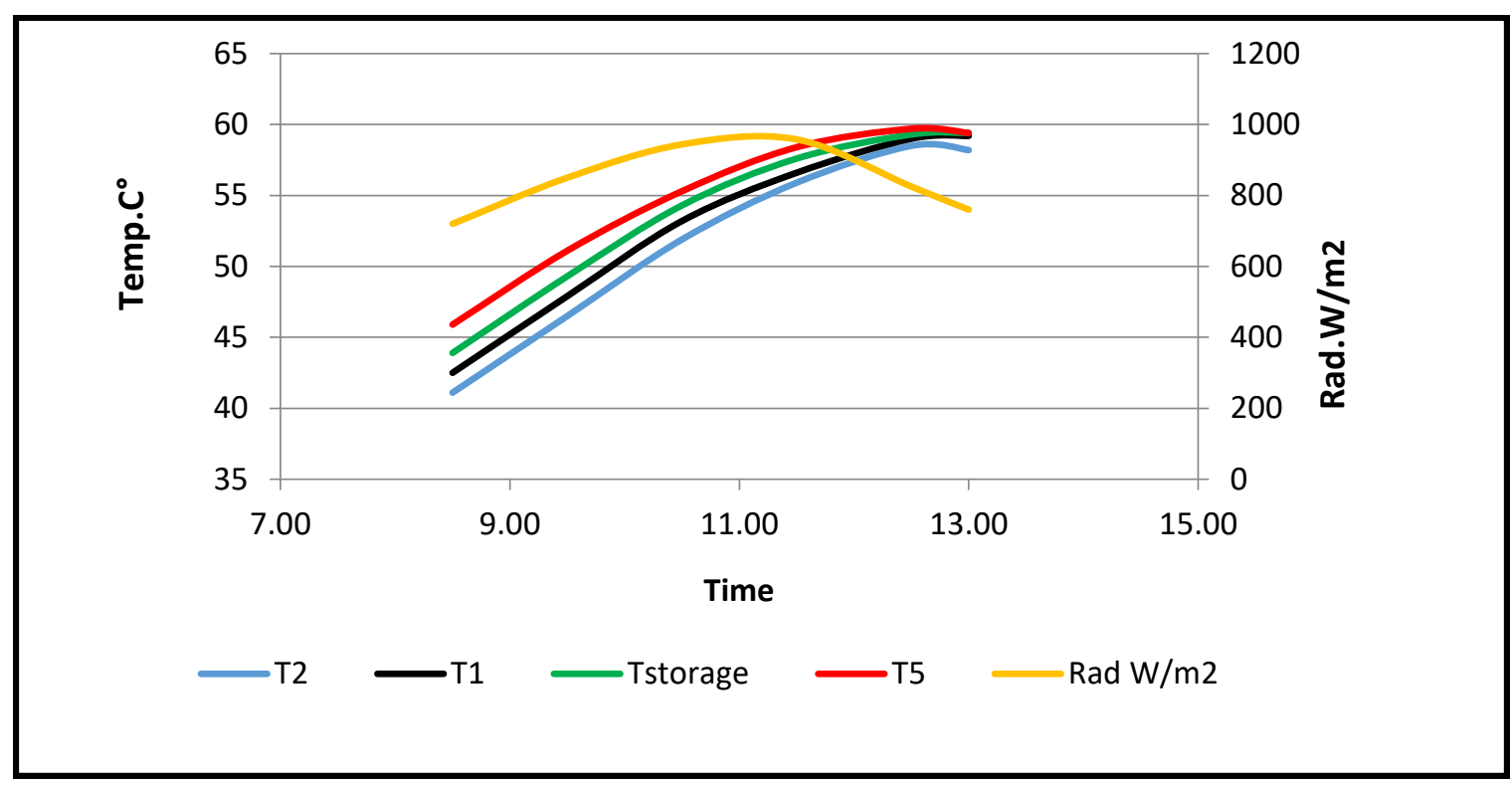

Figure (10). Relation between temperatures of system parameters, solar radiation with time at flow rate $50 \mathrm{l} / \mathrm{h}$. 


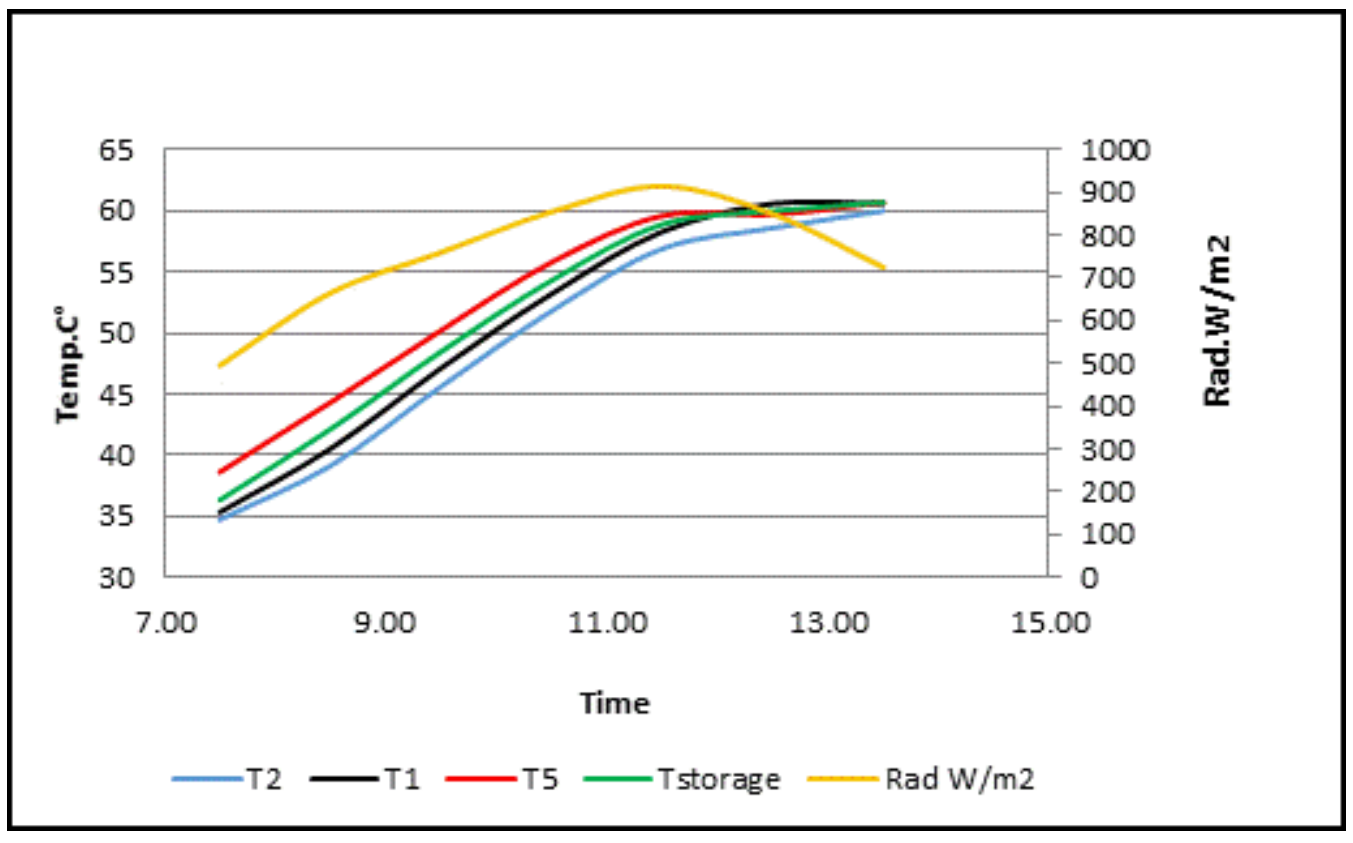

Figure (11). Relation between temperature of system parameters, solar radiation with time at flow rate $70 \mathrm{l} / \mathrm{h}$.

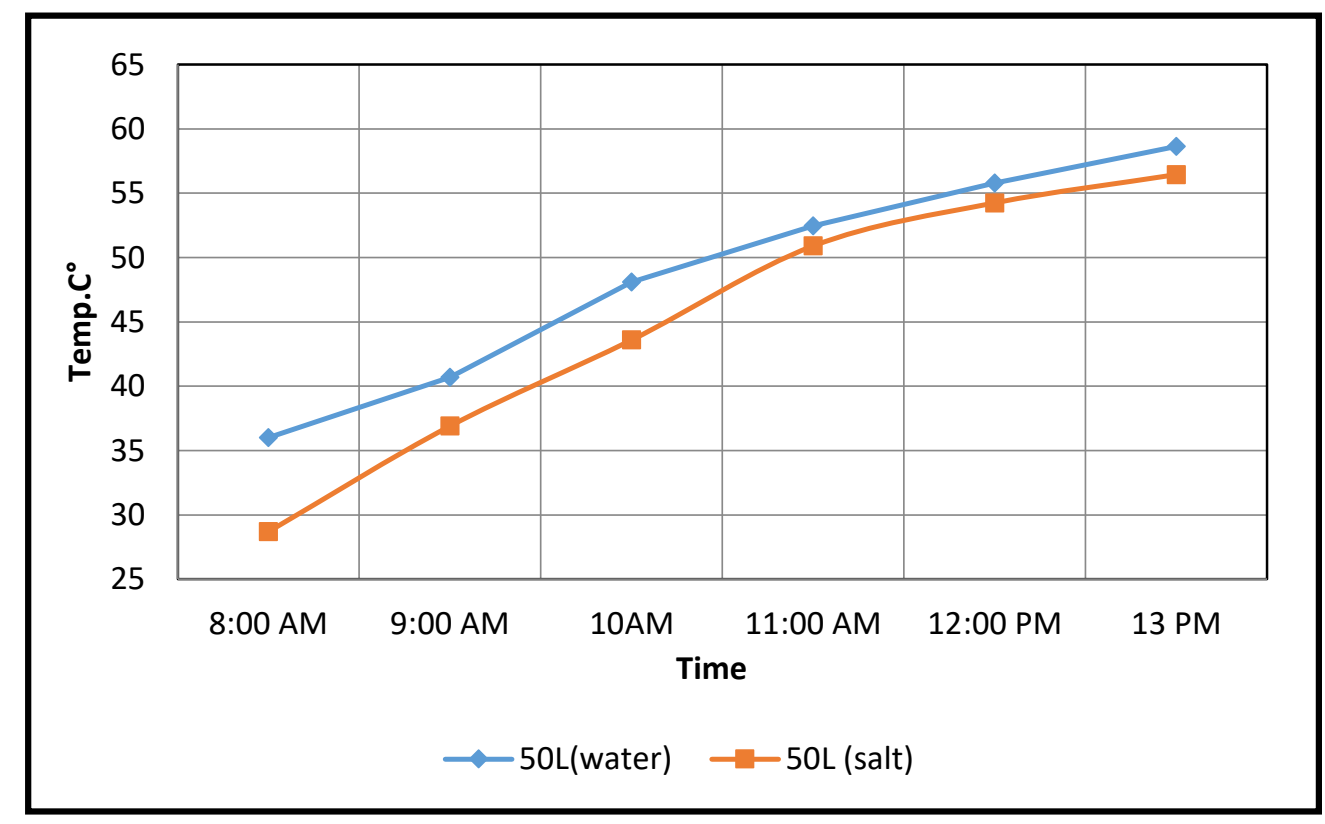

Figure (12). Temperature comparison for the water in TES using molten salts and water as storage media. 


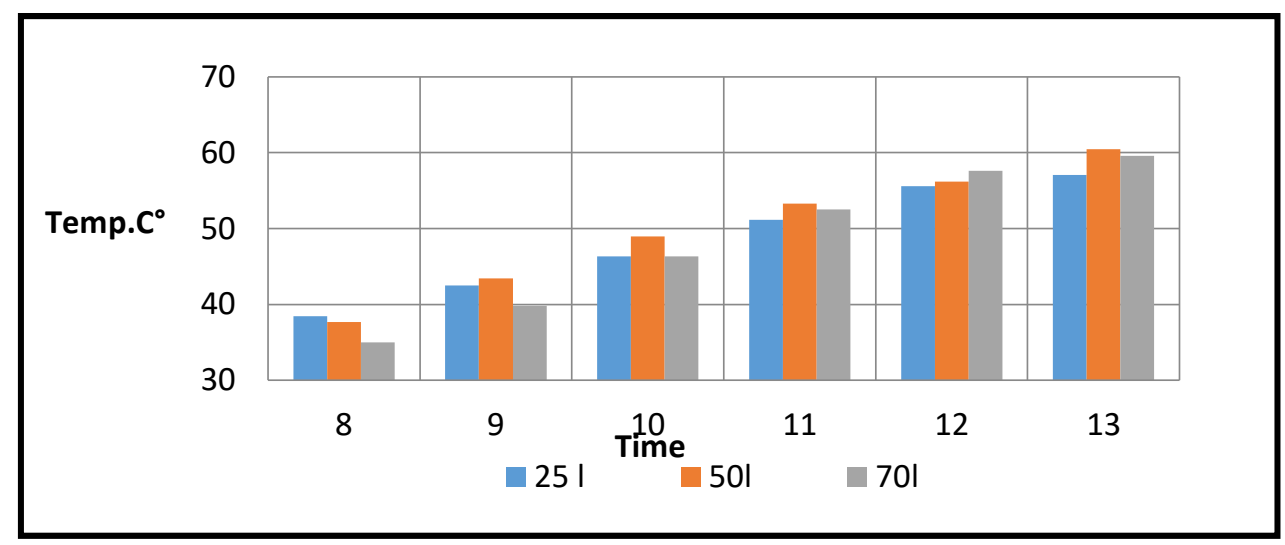

Figure (13). Thermal storage tank water temperature for different flow rates.

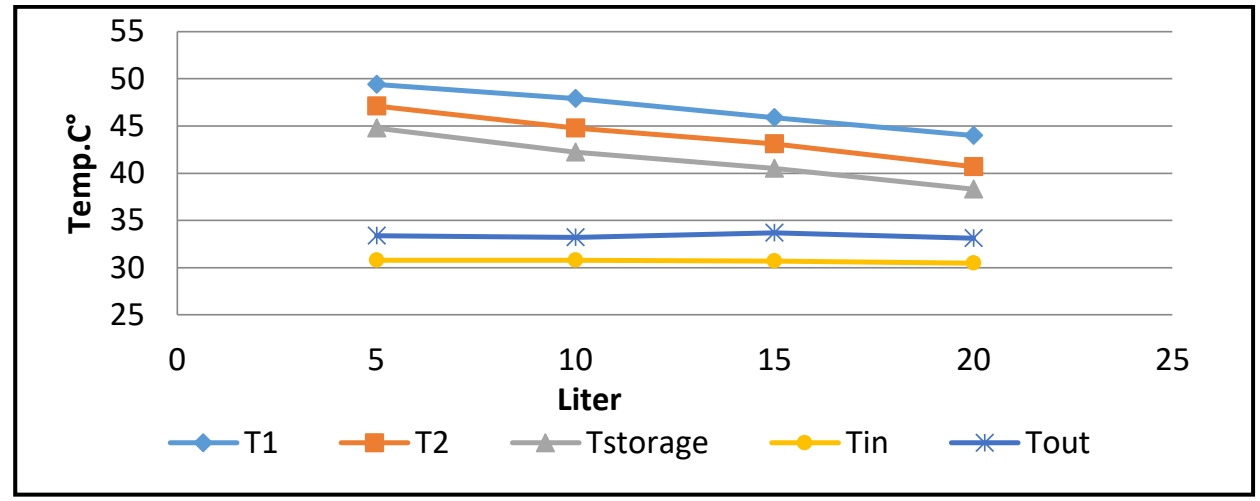

Figure (14). Effect of the amount of water withdrawal on the temperature of the storage medium (using water).

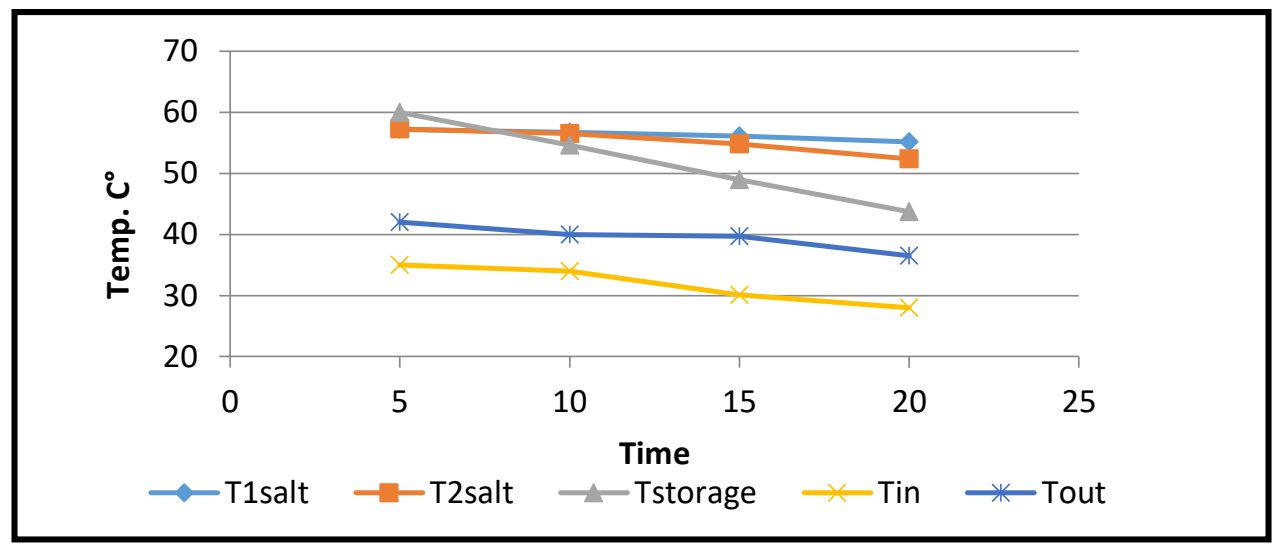

Figure (15). Effect of the amount of water withdrawal on the temperature of the storage medium.

\section{Conclusions}

when specify the molten salts as a heat storage media at low range, the binary eutectic mixture $60 \%$ of Calcium nitrate and 40\% Magnesium nitrate are experimentally confirming as a potential TES materials according to the melting point, thermal stability and thermal heat capacity of these binary salts, although the other proportions have same criteria for thermal storage media as well. Experiments determined that potential improvements in power cycle preheating were proposed based on the Low melting point of binary eutectic salt properties. The proposal idea can be applied in a residential solar water collector instead of using auxiliary electric heater after sunset. 


\section{References}

[1] S. Sami and N. Etesami, "Improving Thermal Characteristics and Stability of Phase Change Material Containing $\mathrm{TiO}_{2}$ Nanoparticles after Thermal Cycles for Energy Storage”, Applied Thermal Engineering, vol. 124, pp. 346-352, 2017.

[2] P. J.E and D. S.R, "Assessment of Molten-Salt Solar Central-Receiver Freeze-Up and Recovery Events", https://digital.library.unt.edu/ark:/67531/metadc670401/, 1996.

[3] S. Ladkany, W. Culbreth and N. Loyd, "Molten Salts and Applications I: Molten Salt History; Types, Thermodynamic and Physical Properties, and Cost", Journal of Energy and Power Engineering, vol. 12, pp. 507-516, 2018.

[4] Y. Z. and G. S.V, "Melting of change Materials with volume change in Metal Foams", Journal of heat transfer, vol. 132, PP. 062301, 2010.

[5] Laing D., Baur T., Lehmann D.and Baht C.” Development of Thermal Energy Storage System for Parabolic Trough Power plants with Direct Steam Generation” Journal of Solar Energy Engineering, vol. 132, pp. $021011,2010$.

[6] V. Y. K. A. Oztop HF, and A.E, "Forecasting of thermal energy storage performance of phase change material in a solar collector using soft computing techniques", Expert system application pp. 2724-2732, 2010.

[7] H. D, G. V. P. X, and B. Karim "High Performance Storage Composite for The Enhancement of Solar Domestic Hot Water Systems", part1, storage material investigation, solar energy; vol. 85, pp. 1021-1027, 2011.

[8] M. Shirinbakhsh, N. Mirkhan and B. Sajadi, "Optimization of the PCM Integrated Solar Domestic Hot Water System Under Different Thermal Stratification Conditions”. EES, vol. 4, pp. 271-279, Dec 2016.

[9] Tayeb, A.M, "A Simulation Model for A Phase Change Energy Storage System: Experimental and Verification", Energy Conversion and Management, vol. 34, no.4, pp 243-250, 1993.

[10] A. G. Ferna'ndez, H. Galleguillos, E. Fuentealba, and F. J. Pe'rez," Thermal Characterization of HITEC Molten Salt for Energy Storage in Solar Linear Concentrated Technology", Akade miai Kiado', Budapest, Hungary, 2015.

[11] C. Villada, F. Bolívar, F. Jaramillo, J. G. Castaño, F. Echeverría, "TheNormal Evaluation of Molten Salts for Solar Thermal Energy Storage", International Conference on Renewable Energies and Power Quality (ICREPQ'14) Cordoba (Spain), 8th to 10th April, 2014.

[12] A. Sharma, V.V. Tyagi, C.R. Chen, and D. Buddhi, "Review on Thermal Energy Storage with Phase Change Materials and Applications", Renewable and Sustainable Energy Reviews, vol. 13, pp. 318-34, 2009.

[13] D. Barlev A. C. R. Vidu b.c, P. Stroeve, "Innovation in Concentrated Solar Power", Solar Energy Materials \& Solar Cells, vol. 95, pp. 2703-2725, 2011. 